\title{
ENERGY INPUT ON COVER CROP CULTIVATION
}

\author{
Leszek Majchrzak $^{\mathrm{a}}$, Tomasz Piechota ${ }^{\mathrm{a}}$, Tomasz Piskier ${ }^{\mathrm{b}}$ \\ ${ }^{\mathrm{a}}$ Department of Agronomy, Poznan University of Life Sciences \\ ${ }^{\mathrm{b}}$ Agri-biotechnology Department, Koszalin University of Technology \\ *Corresponding author: e-mail leszmaj@up.poznan.pl
}

\begin{tabular}{|c|c|}
\hline ARTICLE INFO & ABSTRACT \\
\hline $\begin{array}{l}\text { Article history: } \\
\text { Received: May } 2017 \\
\text { Received in the revised form: } \\
\text { August } 2017 \\
\text { Accepted: August } 2017 \\
\end{array}$ & $\begin{array}{l}\text { The research was carried out in 2015-2016 at the Research Station } \\
\text { Brody belonging to Poznan University of Life Sciences. The experi- } \\
\text { ment was assumed with blocks randomized in four replications. The } \\
\text { aim of the study was to determine the size and structure of energy } \\
\text { inputs incurred on cover crops cultivation in different soil tillage }\end{array}$ \\
\hline $\begin{array}{l}\text { Key words: } \\
\text { strip tillage, } \\
\text { white mustard, } \\
\text { field pea, } \\
\text { energy efficiency index }\end{array}$ & $\begin{array}{l}\text { systems. The cumulative energy consumption methodology was used } \\
\text { to analyse the energy expenditure on field pea and white mustard seed. } \\
\text { Based on the research, it was found that sowing field pea as a cover } \\
\text { crop as compared to white mustard increased the cumulative energy } \\
\text { input by } 63.2 \% \text {. Applied sowing technologies, regardless of cover } \\
\text { crop species, reduced cumulative energy use by } 22.5 \% \text { (strip tillage) } \\
\text { and direct sowing by } 40.7 \% \text { as compared to traditional tillage. The } \\
\text { structure of energy input depended on the type of used cover crop } \\
\text { species, which was based on the energy value of the seed used. The } \\
\text { value of the energy efficiency index for growing both cover crop } \\
\text { species increased with the simplification of the tillage. }\end{array}$ \\
\hline
\end{tabular}

\section{The list of symbols}

Ecg - energy consumption of the tractor operation, $\left(\mathrm{MJ}^{\mathrm{n}} \mathrm{ha}^{-1}\right)$

$\mathrm{Ee} \quad$ - energy efficieny index, (-)

Em $\quad$ - energy consumption of the machines operation, (MJ.ha $\left.{ }^{-1}\right)$

Etech - energy consumption of the investigated technology, $\left(\mathrm{MJ} \cdot \mathrm{ha}^{-1}\right)$

Mc - total weight of tractors used for performance of a particular treatment, $(\mathrm{kg})$

$\mathrm{Mm} \quad$ - total weight of a machine used for performance of a particular treatment, (kg)

$\mathrm{Pe} \quad$ - energy value of yield, $\left(\mathrm{MJ} \cdot \mathrm{ha}^{-1}\right)$

Tnc - normative number of hours of operation of a tractor in the duration of its use, (h)

Tnm - normative number of hours of operation of a machine in the duration of its use, (h)

Wec - index of a unit energy consumption of tractors, $\left(\mathrm{MJ} \cdot \mathrm{kg}^{-1}\right)$

Wem - index of a unit energy consumption of a machine, $\left(\mathrm{MJ} \cdot \mathrm{kg}^{-1}\right)$

$\mathrm{Wz} \quad$ - index of a unit energy consumption of spare parts, $\left(\mathrm{MJ} \cdot \mathrm{kg}^{-1}\right)$ 


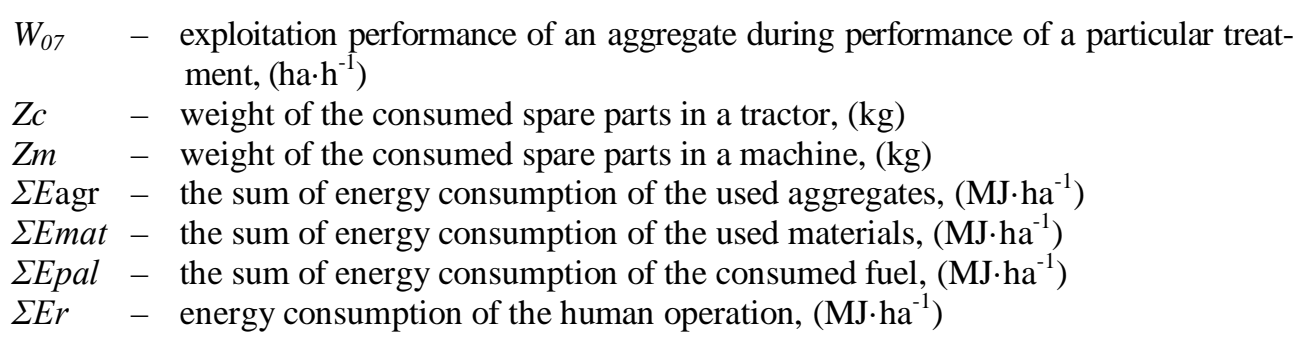

Progress in agriculture has been related with the increase of cultivation intensity for thousand of years. Unfortunately, except for many advantages, intensive cultivation brings numerous problems which grow with time. High costs of mechanical cultivation and time needed to perform it, which was always perceptible for farmers, are more clearly accompanied by problems related to reduction of the humus content, deterioration of the structure, soil erosion and its excessive compaction. The increasing simultaneous simplification of crop rotation additionally impoverishes biodiversity of agrocenosis. It is not unusual that together with technical possibilities, a trend to limit the mechanical tillage, even its absolute abandonment for the benefit of the direct drilling has started (Lal et al., 2007; Morris et al., 2010). "Preservation" is one of the tasks of simplified tillage technologies that means not only protection against degradation, but also reconstruction and improvement of the quality. However, the limitation of the cultivation intensity is not sufficient to consider it as fully preserving if the continuance of the plant cover, live or dead, forming a bedding on the surface, is not maintained (Reycosky, 2015). Cover crops which perform many other important organic and production functions may constitute a supplement of soil cover (Hartwig and Ammon, 2002; Małecka et al., 2004; Snapp et. al., 2005).

Available technologies of simplified cultivation differ among themselves with a depth of cultivation, intensity of mixing plant residues and energy input (Morris et al., 2010). Strip tillage is one of the newest and the least investigated in soil and climatic conditions of Poland. There has been so far no information on the use of the said technology in cover crop cultivation.

Cover crop cultivation requires energy and financial inputs and is burdened with a considerably high risk of failure. The impact of cover crops is not always explicit. Sometimes they can cause deterioration of soil properties, phytosanitary condition and reduction of the successive plant yield (Jaskulska and Gałęzewski, 2009).

The solution that becomes more and more popular is the use of energy account for evaluation and comparison of the plant production technology (Czarnocki, 2013); this rule may be also used for cultivation of a cover crop.

The objective of the research was to determine the size and structure of energy inputs incurred on the cover crop cultivation and comparison of the value of energy efficiency index of the applied tillage systems and cover crops.

\section{Methodology of work}

Tests were carried out in 2015-2016 in the Experimental and Educational Centre Brody of Poznan Life Sciences University. A two-factor static field experiment was set in the 
system of blocks drawn in four iterations in 2006. The 1 st degree factor was a cover crop type: white mustard (sowing $20 \mathrm{~kg} \cdot \mathrm{ha}^{-1}$ ) and field pea (sowing $100 \mathrm{~kg} \cdot \mathrm{ha}^{-1}$ ). The 2 nd degree factor was a method of field cultivation for cover crop sowing after spring wheat harvesting which was cultivated in the main yield. The applied levels of the factor are as follows: traditional cultivation - disc harrow, strip tillage, direct drilling. Dry mass of cover crop was determined in autumn from the surface area of $0.5 \mathrm{~m}^{2}$ in two iterations on each field. Roots were washed out in a screen with diameter of meshes of $0.25 \mathrm{~mm}$. After they were separated from organic and mineral impurities they were subjected to drying in the temperature of $105^{\circ} \mathrm{C}$ to the solid mass and then milled. The content of macroelements $\mathrm{N}, \mathrm{P}, \mathrm{K}$ and $\mathrm{Ca}$ were determined with standard methods. Fertilization value of cover crop was calculated based on the dry mass yield and content of nutrients N, P, K and Ca.

Methodology of accumulated energy consumption was applied for analysis of energy inputs incurred on white mustard and field pea cultivation (Anuszewski et al., 1979; Wójcicki, 2002).

$$
E_{\text {tech }}=\sum E_{\text {mat }}+\sum E_{\text {agr }}+\sum E_{\text {pal }}+\sum E_{r} \quad\left(M J \cdot h a^{-1}\right)
$$

Because determination of the amount of energy brought in the form of human labour $\left(\Sigma \mathrm{E}_{\mathrm{r}}\right)$ in field conditions was not possible to determine, this component of accumulated energy was omitted and the formula assumed a form suggested by Piskier (Piskier, 2011):

$$
E_{\text {tech }}=\sum E_{\text {mat }}+\sum E_{a g r}+\sum E_{p a l} \quad\left(M J \cdot h a^{-1}\right)
$$

In order to determine energy consumption of the tractor operation the following relations were used (Anuszewski et al., 1979; Wójcicki 2002):

$$
E_{c g}=\frac{\mathrm{Mc} \cdot W e c+Z c \cdot W z}{T n c \cdot W_{07}} \quad\left(M J \cdot h a^{-1}\right)
$$

Analogous formula was applied for calculation of energy consumption of operating machines

$$
E_{m}=\frac{M m \cdot W e m+Z m \cdot W z}{T n m \cdot W_{07}} \quad\left(M J \cdot h a^{-1}\right)
$$

Energy consumption of operating aggregates was calculated by summing the energy consumption of a tractor and a machine cooperating therewith.

Efficiency of machines was determined with the use of simplified timing and fuel consumption during particular treatments was determined through a direct measurement. Energy brought in the form of materials was calculated by multiplication of the weight of material consumed during production by the value of energy included therein assuming: for the sown material in the form of field pea $9 \mathrm{MJ} \cdot \mathrm{kg}^{-1}$, white mustard $12 \mathrm{MJ} \cdot \mathrm{kg}^{-1}$, for diesel oil $48 \mathrm{MJ} \cdot \mathrm{kg}^{-1}$. The fertilization value was calculated based on the dry mass yield and content of elements assuming for $\mathrm{N} 77 \mathrm{MJ} \cdot \mathrm{kg}^{-1}, \mathrm{~K}_{2} \mathrm{O} 10 \mathrm{MJ} \cdot \mathrm{kg}^{-1}, \mathrm{P}_{2} \mathrm{O}_{5} 15 \mathrm{MJ} \cdot \mathrm{kg}^{-1}$ and $\mathrm{CaO}$ $6 \mathrm{MJ} \cdot \mathrm{kg}^{-1}$ (Wójcicki, 2002). Energy performance index was calculated from the relation provided by Harasim (1997):

$$
E_{e}=\frac{\mathrm{Pe}_{\mathrm{e}}}{E_{\text {tech }}}
$$


Results of the research were subjected to statistical analysis with the use of analysis of variance for experimental experiments in the split-plot system with the use of ANALVAR$5.2 \mathrm{FR}$ program. For a detailed comparison of the means, Tukeys test at the level of significant of $\mathrm{p} \leq 0.05$ was used.

\section{Results of research and their analysis}

The structure of energy inputs in the experiment was considered with regard to the amount of energy brought in the form of agrotechnical treatments (or groups of treatments). The total average energy expenditure incurred for the field pea production was at the average for two years of research $1618 \mathrm{MJ} \cdot \mathrm{ha}^{-1}$ and white mustard $958 \mathrm{MJ} \cdot \mathrm{ha}^{-1}$ (Tab. 1). Both in the field pea and mustard cultivation, simplification of field cultivation resulted in the reduction of energy inputs. A difference between traditional cultivation and direct drilling for pea was $33.9 \%$ and for mustard $51.0 \%$. Sowing of cover crops in the strip tillage technology caused reduction of energy inputs in the form of used units by $15 \%$ and in case of direct drilling by $30.1 \%$. The amount of energy brought in the form of the consumed fuel decreased also with simplification of field cultivation. Assuming for both cover crops that the consumed fuel was $100 \%$ in the traditional technology, in the strip cultivation it was lower by $37.5 \%$ and in direct drilling it was $67.2 \%$. Dobek (2005) obtained similar results of research indicating the reduction of the energy input brought in the form of fuel with simplification of field cultivation.

Table 1.

Amount and structure of energy input used on cover crop cultivation depends on soil tillage system, mean in years 2015-2016

\begin{tabular}{|c|c|c|c|c|}
\hline \multirow{2}{*}{ Tillage system } & \multicolumn{3}{|c|}{ Energy brought in $\left(\mathrm{MJ} \cdot \mathrm{ha}^{-1}\right)$} & \multirow{2}{*}{$\begin{array}{c}\text { Accumulated } \\
\text { energy input } \\
\left(\mathrm{MJ} \cdot \mathrm{ha}^{-1}\right)\end{array}$} \\
\hline & Aggregates & Fuel & Materials & \\
\hline \multicolumn{5}{|c|}{ Field pea } \\
\hline Traditional & 133 & 930 & 900 & 1963 \\
\hline Strip tillage & 113 & 581 & 900 & 1594 \\
\hline Direct drilling & 93 & 305 & 900 & 1298 \\
\hline Mean & 113 & 605 & 900 & 1618 \\
\hline \multicolumn{5}{|c|}{ White mustard } \\
\hline Traditional & 133 & 930 & 240 & 1303 \\
\hline Strip tillage & 113 & 581 & 240 & 934 \\
\hline Direct drilling & 93 & 305 & 240 & 638 \\
\hline Mean & 113 & 605 & 240 & 958 \\
\hline
\end{tabular}

Cover crop cultivation in the technology of direct drilling consumed the least energy (table 2). It was caused by lower energy input incurred in the form of applied units (by $15 \%$ referred to the strip cultivation and $30.1 \%$ with reference to traditional cultivation) as well as a lower amount of energy brought in the form of consumed fuel by $47.7 \%$ in comparison to strip cultivation and $67.3 \%$ with reference to disc harrow cultivation before cover crop sowing. The energy input in the form of materials was not varied in the investigated technologies and it was in combinations with pea sowing $-900 \mathrm{MJ} \cdot \mathrm{ha}^{-1}$, and mustard 
Energy imput...

$-240 \mathrm{MJ} \cdot \mathrm{ha}^{-1}$. Field pea sowing as a cover crop with reference to white mustard resulted in the increase of the accumulated energy by $63.2 \%$.

Table 2.

Influence of soil tillage system on amount and structure of energy input used for cover crop

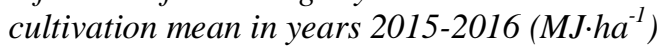

\begin{tabular}{lcccc}
\hline \multirow{2}{*}{ Tillage system } & \multicolumn{3}{c}{ Energy brought in } & $\begin{array}{c}\text { Accumulated } \\
\text { energy input }\end{array}$ \\
\cline { 2 - 4 } Traditional & Aggregates & Fuel & Materials & 1632 \\
Strip tillage & 133 & 929 & 570 & 1264 \\
Direct drilling & 113 & 581 & 570 & 968 \\
Mean & 93 & 304 & 570 & 1288 \\
\hline Catch crop & 113 & 605 & 570 & 1704 \\
Field pea & 118 & & & 1044 \\
White mustard & 118 & 686 & 240 & 1374 \\
Mean & 118 & 686 & 570 & \\
\hline
\end{tabular}

The energy value of the total yield of biomass (consisting of the mass of the aboveground parts and roots) of white mustard was considerably higher than the field pea obtained from cultivation (Table 3). Direct drilling proved to be the most efficient cultivation technology. The highest energy value for this manner of cultivation was confirmed with reference to white mustard. Sown in this technology generated the highest energy value of the root yield, above-ground parts and the total biomass yield. Significance of the cooperation of the experimental factors was determined. If white mustard was sown in direct drilling technology (applied permanently) then both the yield of the above-ground parts, roots and general crop of dry mass was significantly the highest. The increase of the yield of plants on stands with a long-term use of non-tillage cutlivation or direct drilling was also proved by Weber (2010). Dopka et al., (2012) prove variability of the obtained yield of the above-ground parts biomass in relation to the manner of preparing the field for their sowing. The most favourable, with regard to the amount of ground parts biomass, was application of the average tillage or skimming before sowing of the cover crop. The worst average effects were in case of disc harrowing. The authors also indicate a lower yield of biomass of leguminous plant angustifoliate lupine in comparison to white mustard. The higher yield of white mustard in comparison to leguminous mixture (angustifoliate lupine + field pea) was also proved in the research by Gawęda et al., (2014).

Field pea produced the highest yield of dry mass in the strip tillage technology and significance of differences was confirmed with reference to the traditional technology (Table 4). On the other hand, mustard had significantly the highest yield in direct drilling technology. Effectiveness of energy inputs depended on the investigated factors. More favourable effects (increase of the value of the energy efficiency index) was obtained along with simplification of soil cultivation. Direct drilling of field pea in comparison to the traditional technology resulted in the increase by $76.5 \%$ and white mustard - almost twofold. Cultivation of field pea in the traditional technology proved to be the most energy consuming. Szulc and Dubas (2014) obtained various values of the energy efficiency index in their research concerning simplification in field cultivation for corn sowing. The authors proved reduction of its value after application of direct drilling in corn cultivation. 
Leszek Majchrzak, Tomasz Piechota, Tomasz Piskier

Table 3.

Yield energy value depend on cover crop and tillage system mean in years 2015-2016 $\left(M J \cdot h a^{-1}\right)$

\begin{tabular}{|c|c|c|c|c|}
\hline \multirow{2}{*}{ Cover crop } & \multicolumn{4}{|c|}{ Tillage system } \\
\hline & Traditional & Strip tillage & Direct drilling & Mean \\
\hline & \multicolumn{4}{|c|}{ Aboveground plant biomass } \\
\hline Field pea & $2188 a^{*}$ & 2910a & $2530 a$ & $2543 \mathrm{~A}$ \\
\hline White mustard & $4286 b$ & 4109b & 6501c & 4965B \\
\hline \multirow[t]{2}{*}{ Mean } & $3237 A^{* *}$ & 3509A & 4515B & - \\
\hline & \multicolumn{4}{|c|}{ Roots } \\
\hline Field pea & $62 \mathrm{a}$ & $140 \mathrm{a}$ & 103a & $102 \mathrm{~A}$ \\
\hline White mustard & $687 b$ & $695 b$ & 1096c & $826 B$ \\
\hline \multirow[t]{2}{*}{ Mean } & $374 \mathrm{~A}$ & 417A & 599B & - \\
\hline & \multicolumn{4}{|c|}{ Total biomass (aboveground plant biomass + roots) } \\
\hline Field pea & 2251a & 3050a & 2634a & $2645 \mathrm{~A}$ \\
\hline White mustard & 4973b & $4805 b$ & 7598c & 5792B \\
\hline Mean & $3612 \mathrm{~A}$ & 3927A & 5116B & - \\
\hline
\end{tabular}

Table 4

Yield and energy efficiency index value in cover crop cultivation, average in years 2015-2016

\begin{tabular}{|c|c|c|c|}
\hline \multirow[b]{2}{*}{ Tillage system } & \multicolumn{3}{|c|}{ Parameter } \\
\hline & $\begin{array}{c}\text { Yield d.m. } \\
\left(\mathrm{t} \cdot \mathrm{ha}^{-1}\right)\end{array}$ & $\begin{array}{l}\text { Accumulated energy } \\
\text { input }\left(\mathrm{MJ} \cdot \mathrm{ha}^{-1}\right)\end{array}$ & Index of efficiency \\
\hline \multicolumn{4}{|c|}{ Field pea } \\
\hline Traditional & $0.73 a$ & 1963 & 1.15 \\
\hline Strip tillage & $0.97 \mathrm{~b}$ & 1594 & 1.92 \\
\hline Direct drilling & 0.82ab & 1298 & 2.03 \\
\hline \multicolumn{4}{|c|}{ White mustard } \\
\hline Traditional & $1.87 \mathrm{a}$ & 1303 & 3.81 \\
\hline Strip tillage & $1.69 \mathrm{a}$ & 934 & 5.14 \\
\hline Direct drilling & $2.57 \mathrm{~b}$ & 638 & 11.91 \\
\hline
\end{tabular}

different small case letters among treatment means indicate significant difference according to Tuckey test $\mathrm{p} \leq 0.05$

\section{Conclusions}

1. Field pea sowing as a cover crop with reference to white mustard resulted in the increase of the accumulated energy input by $63.2 \%$.

2. The applied sowing technologies regardless the cover crop type caused reduction of the accumulated energy input by $22.5 \%$ (strip tillage) and direct drilling by $40.7 \%$ with reference to the traditional tillage. 
Energy imput...

3. The structure of energy expenditures depended on the type of the applied cover crop which resulted from energy value of the applied sowing material.

4. The value of the energy efficiency index for cultivation of both cover crops increased together with simplification of tillage.

\section{References}

Anuszewski, R., Pawlak, J., Wójcicki, Z. (1979). Energochłonność produkcji rolniczej. Metodyka badań energochłonności produkcji surowców żywnościowych. IBMER Warszawa.

Czarnocki, S. (2013). Ocena energetyczna alternatywnych technologii przygotowania roli do siewu jęczmienia ozimego. Inżynieria Rolnicza, 3(146), 69-75.

Dobek, T. (2005). Energetyczna i ekonomiczna ocena różnych technologii uprawy roli do siewu rzepaku ozimego. Inżynieria Rolnicza, 3(63), 133-140.

Dopka, D., Korsak-Adamowicz, M., Starczewski, J. (2012). Biomasa międzyplonów ścierniskowych i ich wpływ na plonowanie żyta jarego w monokulturowej uprawie. Fragmenta Agronomica, 29(2), 27-32.

Gawęda, D., Wesołowski, M., Kwiatkowski, C. (2014). Weed infestation of spring barley (Hordeum vulgare L.) depending on the cover crop and weed control method. Acta Agrobotanica, 67(1), 77-84.

Harasim, A. (1997). Możliwości kompensacji ujemnego wpływu stanowiska na plonowanie i efektywność produkcji pszenicy ozimej. II Efektywność energetyczna i ekonomiczna. Pamętnik Putawski, 111, 73-87.

Hartwig, N., Ammon, H. (2002). Cover crops and living mulches. Weed Sciences, 50, 688-699.

Jaskulska, I., Gałęzewski, L. (2009). Aktualna rola międzyplonów w produkcji roślinnej i środowisku. Fragmenta Agronomica, 26(3), 48-57.

Lal, R., Reicosky, D., Hanson, J. (2007). Evolution of the plow over 10,000 years and the rationale for no-till farming. Soil Tillage Research, 93, 1-12.

Małecka, I., Blecharczyk, A., Pudełko, J. (2004). Wartość nawozowa międzyplonów ścierniskowych w różnych systemach uprawy roli. Prace Komisji Nauk Rolniczych Komisji Nauk Leśnych PTPN, 97, 42-48.

Morris, N., Miller, P., Orson, J., Froud-Williams, R. (2010). The adoption of non-inversion tillage systems in the United Kingdom and the agronomic impact on soil, crops and the environment - a review. Soil \& Tillage Research, 108, 1-15.

Piskier, T. (2011). Efektywność energetyczna produkcji biomasy w teorii i praktyce. Technika Rolnicza Ogrodnicza Leśna, 3, 5-7.

Reycosky, D. (2015). Conservation tillage is not conservation agriculture. Journal Soil Water Consist, 70, 5, 103A-108A.

Snapp, S., Swinton, R., Labarta, R., Mutch, D., Black, J.R., Leep, R., Nyiraneza, J., O’Neil, K. (2005). Evaluating cover crops for benefits, costs and performance within cropping system niches. Agronomy Journal, 97, 322-332.

Szulc, P., Dubas, A. (2014). Ekonomiczna i energetyczna ocena uproszczonych technologii uprawy roli pod kukurydzę. Nauka Przyroda Technologie, 8, 2-27.

Weber, R. (2010). Przydatność uprawy konserwującej w rolnictwie zrównoważonym. Monografie i Rozprawy Nauk. IUNG-PIB, 2010, 25, 1-72.

Wójcicki, Z. (2002). Wyposażenie i nakłady materiałowo energetyczne w rozwojowych gospodarstwach rolniczych. IBMER Warszawa. ISBN 83-86264-62-4. 
Leszek Majchrzak, Tomasz Piechota, Tomasz Piskier

\title{
NAKLADY ENERGETYCZNE UPRAWY MIĘDZYPLONÓW ŚCIERNISKOWYCH
}

\begin{abstract}
Streszczenie. Badania przeprowadzono w latach 2015-2016 w ZDD Brody należącym do Uniwersytetu Przyrodniczego w Poznaniu. Doświadczenie założono metodą bloków losowanych w 4 powtórzeniach. Celem badań była ocena wielkości i struktury nakładów energetycznych poniesionych na uprawę międzyplonów w zróżnicowanych systemach uprawy roli. Do analizy nakładów energetycznych ponoszonych na wysiew grochu polnego i gorczycy białej zastosowano metodykę energochłonności skumulowanej. Na podstawie przeprowadzonych badań stwierdzono, że wysiew grochu polnego jako międzyplonu ścierniskowego w odniesieniu do gorczycy białej powodował zwiększenie skumulowanego nakładu energii o 63,2\%. Zastosowane technologie wysiewu niezależnie od rodzaju międzyplonu powodowały zmniejszenie nakładu energii skumulowanej o 22,5\% (uprawa pasowa), a siew bezpośredni o 40,7\% w odniesieniu do uprawy tradycyjnej. Struktura nakładów energetycznych była uzależniona od rodzaju zastosowanego międzyplonu, co wynikało z wartości energetycznej użytego materiału siewnego. Wartość wskaźnika efektywności energetycznej dla uprawy obu międzyplonów wzrastała wraz z uproszczeniem uprawy roli.
\end{abstract}

Słowa kluczowe: uprawa pasowa, gorczyca biała, groch polny, wskaźnik efektywności energetycznej 